\title{
Omission of Radiation Therapy (RT) for Metaplastic Breast Cancer (MBC): A Review Article
}

\author{
Omer Sager ${ }^{1}$, FerratDincoglan ${ }^{1}$, Selcuk Demiral ${ }^{1}$, Bora Uysal ${ }^{1}$, Hakan Gamsiz ${ }^{1}$, \\ Onurhan Colak $^{1}$, Fatih Ozcan ${ }^{1}$, Bahar Dirican ${ }^{1}$, Murat Beyzadeoglu ${ }^{1}$ \\ ${ }^{1}$ Department of Radiation Oncology; University of Health Sciences, Gulhane Medical Faculty, \\ Ankara, Turkey
}

*Corresponding Author: Dr. Omer SAGER, University of Health Sciences, Gulhane Medical Faculty, Department of Radiation Oncology, Gn.TevfikSaglam Cad. 06018, Etlik, Kecioren Ankara / TURKEY.

\begin{abstract}
Background: Metaplastic breast c ancer $(M B C)$ is a unique pathological entity characterized by histologic presence of 2 or more cellular types frequently representing mixed epithelial and mesenchymal components. Although comprising a small proportion of all breast cancers, $M B C$ may have a distinct clinical behavior typically with an aggressive disease course in affected patients. Optimal therapeutic strategies for management of $M B C$ have yet to be defined. Extrapolation of evidence for management of frequent types of breast cancer such as invasive ductal carcinoma has been considered, however, MBC may require thorough and more intensive management with its distinctive features given the poorer prognosis and aggressive disease course. Radiation therapy (RT) has a critical role in management of breast cancer with several studies addressing its utility for achieving improved therapeutic outcomes. However, adverse effects of irradiation has been an important concern with improved survival of patients due to more effective therapies. Radiation induced toxicity such as pneumonitis, cardiac morbidities, secondary cancers along with impaired cosmesis may lead to severe consequences although modernized RT techniques and equipment hold promise. Quality of life has been a critical aspect of contemporary management strategies, and sparing of selected patients from adverse effects of irradiation has been considered. Omission of postoperative RT for selected early stage breast cancer patients has been suggested in several studies, however, there is paucity of data on patients with $M B C$.
\end{abstract}

Materials and Methods: Herein, we provide a concise review of RT omission in MBC.

Results: There is not adequate high quality evidence to support RT omission for MBC.

Conclusion: Given the typically poorer prognosis of $M B C$ with an aggressive clinical course in a considerable proportion of affected patients, being more conservative for omission of RT may be considered even in elderly patients with earlier stages of disease.

Keywords: metaplastic breast carcinoma (MBC), omission, radiation therapy (RT)

\section{INTRODUCTION}

Metaplastic breast cancer (MBC) is a unique pathological entity characterized by histologic presence of 2 or more cellular types frequently representing mixed epithelial and mesenchymal components, and although comprising a small proportion of all breast cancers, MBC may have a distinct clinical behavior typically with an aggressive disease course in affected patients [19]. Optimal therapeutic strategies for management of $\mathrm{MBC}$ have yet to be defined. Extrapolation of evidence for management of frequent types of breast cancer such as invasive ductal carcinoma has been considered, however, $\mathrm{MBC}$ may require thorough and more intensive management with its distinctive features given the poorer prognosis and aggressive disease course. Specifical features of MBC may include larger tumor size, triple negative disease, and higher expression of Ki-67 and EGFR [1,6,8,1012].

Radiation therapy (RT) has a critical role in management of breast cancer with several studies addressing its utility for achieving improved therapeutic outcomes [13-16]. However, adverse effects of irradiation has been an important concern with improved survival of patients due to more effective therapies. Radiation induced toxicity such as pneumonitis, cardiac morbidities, secondary cancers along 
with impaired cosmesis may lead to severe consequences although modernized RT techniques and equipment hold promise. Quality of life has been a critical aspect of contemporary management strategies, and sparing of selected patients from adverse effects of irradiation has been considered. Omission of postoperative RT for selected early stage breast cancer patients has been suggested in several studies, however, there is paucity of data on patients with MBC [17-19].Herein, we provide a concise review of RT omission in MBC.

\section{OMISSION OF RT IN MBC}

Omission of RT for selected patients with early breast cancer has been considered in view of important studies addressing this issue [17-19]. Fyles et al. studied on patients $\geq 50$ years old and assigned them to receive tamoxifen alone versus tamoxifen plus breast RT [17]. Median follow-up duration was 5.6 years, and patients not receiving RT had higher local relapse rates at 5 years [17]. Distant relapse, overall survival, and breast cancer death results were not significantly different between the groups [17]. It is important to note that large tumors up to 5 centimeter were included in the study without the requirement of hormon receptor positivity [17]. Nevertheless, subgroup analysis including estrogen receptor positive tumors $\leq 2 \mathrm{~cm}$ has also revealed that local recurrence rate was $3.6 \%$ versus $15.2 \%$ suggesting a critical role for $\mathrm{RT}$ in reducing local recurrences [17].

CALGB 9343 study has included patients over 70 years of age with clinical stage I, estrogen receptor positive breast cancer [18]. Patients were randomly assigned to receive tamoxifen plus irradiation versus tamoxifen alone after lumpectomy [18]. Median follow-up duration of 12.6 years for treated patients, and rates of freedom from local and regional recurrences was $98 \%$ versus $90 \%$ for patients receiving tamoxifen plus irradiation and tamoxifen alone, respectively [18]. Time to mastectomy, time to distant metastasis, breast cancer specific survival, and overall survival results were not significantly different between the 2 groups [18].

PRIME II randomized controlled trial included patients over 65 years of age with low risk features including hormone receptor positivity, axillary node negativity, T1-T2 tumors up to 3 $\mathrm{cm}$ at largest dimension, and clear margins [19]. At a median follow-up duration of 5 years, ipsilateral breast tumor recurrence was $1.3 \%$ and $4.1 \%$ for patints receiving and not receiving RT, respectively [19]. Again, overall survival, regional recurrence, distant metastases, and new breast cancers were not significantly different between the 2 groups [19].

While these studies typically included patients with common breast cancer subtypes, omission of RT for MBC has been poorly addressed in the literature. Haque et al. assessed omission of RT in elderly patients with early stage MBC [20]. All patients were $\geq 70$ years of age and had $\mathrm{T} 1$ or T2, lymph node negative disease [20]. Omission of RT steadily declined over the study period and RT delivery was found to be less likely in the setting of not receiving hormone herapyor age $\geq 80$ years [20]. Multivariate analysis revealed that advanced age, higher $\mathrm{T}$ stage, high grade disease and omission of RT was independently associated with poorer overall survival [20]. Given the independent association with worse survival, the study did not support routine omission of RT for these patients [20].

\section{Conclusions and Future Perspectives}

Given the typically poorer prognosis of $\mathrm{MBC}$ with an aggressive clinical course in a considerable proportion of affected patients, being more conservative for omission of RT may be considered even in elderly patients with earlier stages of disease.

Radiation oncology discipline has undergone unprecedented advances in recent years with adoption of adaptive irradiation strategies, contemporary technologies, along with contemporary treatment delivery techniques such as incorporation of molecular imaging, automatic segmentation methods, Intensity Modulated RadiationT herapy (IMRT), Image Guided Radiation Therapy (IGRT), Adaptive Radiation Therapy (ART), Breathing Adapted Radiation Therapy (BART), and stereotactic irradiation [21-76].

In the context of RT omission for MBC, there is not adequate high quality evidence to support this strategy. Clearly future studies are required to shed light on this issue.

\section{REFERENCES}

[1] Wang J, Zhang WW, Lian CL, Sun JY, He ZY, et al. (2020) The Effect of Post-mastectomy Radiotherapy in Patients With Metaplastic Breast Cancer: An Analysis of SEER Database. Front Oncol 12;9:747.

[2] Haque W, Verma V, Naik N, Butler EB, Teh BS (2018) Metaplastic Breast Cancer: Practice Patterns, Outcomes, and the Role of Radiotherapy. Ann Surg Oncol 25(4):928-936. 
[3] Shah DR, Tseng WH, Martinez SR (2012) Treatment options form etaplastic breast cancer. ISRN Oncol2012:706162.

[4] Tseng WH, Martinez SR (2011) Metaplastic breast cancer: to radiateor not to radiate? Ann Surg Oncol 18:94-103

[5] Toumi Z, Bullen C, Tang AC, Dalal N, Ellenbogen S (2011) Metaplastic breast carcinoma: a case report and systematic review of the literature. PatholInt 61(10):582-588.

[6] Pizza CM, Patel-Parekh L, Cole K, Franko J, Klimberg VS, et al. (2007) Characteristics and treatment of metaplastic breast cancer: analysis of 892 cases from the National Cancer Data Base. Ann Surg Oncol14:166-173.

[7] Beatty JD, Atwood M, Tickman R, Reiner M (2006) Metaplastic breast cancer: clinical signifcance. Am J Surg 191(5):657-664.

[8] Gibson GR, Qian D, Ku JK, Lai LL (2005) Metaplastic breast cancer: clinical features and outcomes. Am Surg71(9):725-730.

[9] Oberman HA (1987) Metaplastic carcinoma of the breast. A clinicopathologic study of 29 patients. Am J Surg Pathol11:918-929.

[10] Yu JI, Choi DH, Huh SJ, Ahn SJ, Lee JS, et al. (2015)Unique characteristics and failure patterns of metaplastic breastc ancer in contrast to invasive ductal carcinoma: a retrospective multicenter case-control study (KROG 13-07). Clin Breast Cancer 15:e105-115.

[11] Nelson RA, Guye ML, Luu T, Lai LL (2015) Survival outcomes of metaplastic breast cancer patients: results from a US population based analysis. Ann Surg Onco 122:24-31.

[12] Jung SY, Kim HY, Nam BH, Min SY, Lee SJ, et al. (2010) Worse prognosis of metaplastic breast cancer patients than other patients with triple-negative breast cancer. Breast Cancer ResTreat 120:627-637.

[13] Yao Y, Chu Y, Xu B, Hu Q, Song Q (2019) Radiotherapyaftersurgery has significantsurvivalbenefitsforpatientswithtriplenegativebreastcancer.CancerMed 8(2):554-563.

[14] Van Maaren MC, de Munck L, de Bock GH, Jobsen JJ, van Dalen T, et al. (2016)10 yearsurvivalafterbreastconservingsurgeryplusradiotherapycomparedwi thmastectomy in early breast cancer in the Netherlands: a population-based study. Lancet Oncol 17(8):1158-1170.

[15] Early Breast Cancer Trialists Collaborative Group (EBCTCG), Darby S, McGale P, Correa C, Taylor C, et al. (2011) Effect of radiotherapy after breast-conserving surgery on 10-year recurrence and 15-year breast cancer death: meta-analysis of individual patient data for 10,801 women in 17 randomised trials. Lancet 378(9804): 1707-1716.

[16] Holli K, Hietanen P, Saaristo R, Huhtala H, Hakama M, et al. (2009) Radiotherapy after segment alresection of breast cancer with favorable prognostic features: 12-yearfollowupresults of a randomized trial. J ClinOncol 27: 927-932.

[17] Fyles AW, McCready DR, Manchul LA, Trudeau ME, Merante P, et al. (2004) Tamoxifen with or without breast irradiation in women 50 years of ageorolder with early breast cancer. NEnglJ Med 351(10):963-970.

[18] Hughes KS, Schnaper LA, Bellon JR, Cirrincione CT, Berry DA, et al. (2013) Lumpectomy plus tamoxifen with or without irradiation in women age 70 years or older with early breast cancer: long-term follow-up of CALGB 9343.J Clin Oncol 31(19):2382-2387.

[19] Kunkler IH, Williams LJ, Jack WJ, Cameron DA, Dixon JM,et al. (2015) Breast-conserving surgery with or without tirradiation in women aged 65 year sorolder with early breast cancer (PRIME II): a randomised, controlled trial. Lancet Oncol 16(3):266-273.

[20] Haque W, Verma V, Butler EB, Teh BS (2018) Omission of radiotherapy in elderly women with early stageme taplastic breast cancer. Breast 38:154-159.

[21] Sager O, DincoglanF, Demiral S, Beyzadeoglu M (2020) Evaluation of Treatment Volume Determination for Irradiation of chordoma: an Original Article. International Journal of Research Studies in Medical and Health Sciences 5(10): 3-8.

[22] Beyzadeoglu M, Dincoglan F, Demiral S, Sager O (2020) Target Volume Determination for Precise Radiation Therapy (RT) of Central Neurocytoma: An Original Article. International Journal of Research Studies in Medical and Health Sciences 5: 29-34.

[23] Sager O, Beyzadeoglu M, Demiral S, Dincoglan F, Gamsiz H, et al. (2020) Utility of SynchronousChemoradiotherapyasaViableAlter nativetoSequentialChemotherapyandRadiothera py(RT) after Breast Conserving Surgery (BCS).Journal of Medical Pharmaceutical and Allied Sciences9(5): 2581-2583.

[24] Sager O, Beyzadeoglu M, Dincoglan F, Demiral S, Uysal B, et al. (2020) A Concise Review of High Dose Rate (HDR) Brachytherapy (BT) Boost as part of Breast Conserving Treatment (BCT) for Breast Cancer (BC). Journal of Medical Pharmaceutical and Allied Sciences 9(5): 2544-2548.

[25] Sager O, Demiral S, Dincoglan F, Beyzadeoglu M (2020)Assessment of Target Volume Definition for Irradiation of Hemangiopericytomas: An Original Article. Canc Therapy \& OncolInt J17(2): 555959.

[26] Dincoglan F, Beyzadeoglu M, Demiral S, Sager O (2020) Assessment of Treatment Volume Definition for Irradiation of Spinal 
Ependymomas: an Original Article. ARC Journal of Cancer Science 6: 1-6.

[27] Sager O, Demiral S, Dincoglan F, Beyzadeoglu M (2020) Target Volume Definition for Stereotactic Radiosurgery (SRS) Of Cerebral Cavernous Malformations (CCMs).CancTherapy\& OncolInt J 15: 555917.

[28] Sager O, Dincoglan F, Demiral S, Beyzadeoglu M (2020) Evaluation of Target Volume Determination for Irradiation of Pilocytic Astrocytomas: An Original Article. ARC Journal of Cancer Science 6: 1-5.

[29] Demiral S, Beyzadeoglu M, Dincoglan F, Sager O (2020) Assessment of Target Volume Definition for Radiosurgery of Atypical Meningiomas with Multimodality Imaging. Journal of Hematology and Oncology Research 3: $14-21$.

[30] Demiral S, Beyzadeoglu M, Dincoglan F, Sager O (2020) Evaluation of Radiosurgery Target Volume Definition for Tectal Gliomas with Incorporation of Magnetic Resonance Imaging (MRI): An Original Article. Biomedical Journal of Scientific\& Technical Research (BJSTR) 27: 20543-20547.

[31] Beyzadeoglu M, Dincoglan F, Sager O, Demiral S (2020) Determination of Radiosurgery Treatment Volume for Intracranial Germ Cell Tumors (GCTS). Asian Journal of Pharmacy, Nursing and Medical Sciences 8: 18-23.

[32] Sager O, Dincoglan F, Demiral S, Beyzadeoglu M (2020) Radiosurgery Treatment Volume Determination for Brain Lymphomas with and without Incorporation of Multimodality Imaging. Journal of Medical Pharmaceutical and Allied Sciences 9: 2398-2404.

[33] Dincoglan F, Demiral S, Sager O, Beyzadeoglu M (2020) Utility of Multimodality Imaging Based Target Volume Definition for Radiosurgery of Trigeminal Neuralgia: An Original Article. Biomed J Sci\& Tech Res 26: 19728-19732.

[34] Dincoglan F, Beyzadeoglu M, Sager O, Demiral S, Uysal B, et al. (2020) A Concise Review of Irradiation for Temporal Bone Chemodectomas (TBC). Arch Otolaryngol Rhinol 6: 016-020.

[35] Sager O, Beyzadeoglu M, Dincoglan F, Demiral S, Gamsiz H, et al. (2020) Multimodality management of cavernous sinus meningiomaswithlessextensivesurgeryfollowed bysubsequentirradiation: Implicationsfor an improvedtoxicity profile. J SurgSurgicalRes 6: 056-061.

[36] Beyzadeoglu M, Sager O, Dincoglan F, Demiral S, Uysal B, et al. (2020) Single Fraction Stereotactic Radiosurgery (SRS) versus Fractionated Stereotactic Radiotherapy
(FSRT) for Vestibular Schwannoma (VS). J Surg SurgicalRes 6: 062-066.

[37] Sager O, Dincoglan F, Demiral S, Uysal B, Gamsiz H, et al. (2020) Adaptiveradiation therapy of breast cancer by repeatedimaging during irradiation. World J Radiol 12: 68-75.

[38] Dincoglan F, Sager O, Demiral S, Gamsiz H, Uysal B, et al. (2019) Fractionated stereotactic radiosurgery for locally recurrent brain metastases after failed stereotactic radio surgery. Indian J Cancer 56: 151-156.

[39] Sager O, Dincoglan F, Demiral S, Uysal B, Gamsiz H, et al. (2019) Utility of Molecular Imaging with 2-Deoxy-2-[Fluorine-18] FluoroDGlucose Positron Emission Tomography (18F-FDG PET) for Small Cell Lung Cancer (SCLC): A Radiation Oncology Perspective. Curr Radiopharm 12: 4-10.

[40] Dincoglan F, Sager O, Demiral S, Beyzadeoglu M (2019) Multimodality Imaging for Radio surgical Management of Arteriovenous Malformations. Asian Journal of Pharmacy, Nursing and Medical Sciences 7: 7-12.

[41] Demiral S, Sager O, Dincoglan F, Beyzadeoglu M (2019) Assessment of target definition based on Multimodality imaging for radio surgical Management of glomus jugulare tumors (GJTs). Canc Therapy \& OncolInt J 15: 555909.

[42] Sager O, Dincoglan F, Demiral S, Gamsiz H, Uysal B, et al. (2019) Utility of Magnetic Resonance Imaging (Imaging) in Target Volume Definition for Radio surgery of Acoustic Neuromas. Int J Cancer ClinRes 6: 119.

[43] Beyzadeoglu M, Sager O, Dincoglan F, Demiral S (2019) Evaluation of Target Definition for Stereotactic Reirradiation of Recurrent Glioblastoma. Arch Can Res 7: 3.

[44] Dincoglan F, Sager O, Demiral S, Beyzadeoglu M (2019) Incorporation of Multimodality Imaging in Radiosurgery Planning for Craniopharyngiomas: An Original Article. SAJ Cancer Sci 6: 103.

[45] Sager O, Dincoglan F, Demiral S, Beyzadeoglu M (2019) Evaluation of Radiosurgery Target Volume Determination for Meningiomas Based on Computed Tomography (CT) And Magnetic Resonance Imaging (MRI). Cancer SciRes Open Access 5: 1-4.

[46] Sager O, Dincoglan F, Demiral S, Gamsiz H, Uysal B, et al. (2019) Evaluation of theImpact of Magnetic Resonance Imaging (MRI) on GrossTumor Volume (GTV) Definition for Radiation Treatment Planning (RTP) of Inoperable High Grade Gliomas (HGGs). Concepts in Magnetic Resonance Part A 2019, Article ID 4282754.

[47] Demiral S, Sager O, Dincoglan F, Beyzadeoglu M (2019) Assessment of Computed Tomography (CT) And Magnetic Resonance 
Imaging (MRI) Based Radio surgery Treatment Planning for Pituitary Adenomas. Canc Therapy \& OncolInt J 13: 555857.

[48] Dincoglan F, Sager O, Uysal B, Demiral S, Gamsiz H, et al. (2019) Evaluation of hypo fractionated stereotactic radiotherapy (HFSRT) to the resection cavity after surgical resection of brain metastases: A single center experience. Indian J Cancer 56: 202-206.

[49] Sager O, Dincoglan F, Demiral S, Uysal B, Gamsiz H, et al. (2019) Breathing adapted radiation therapy for leukemia relapse in the breast: A casere port. World J Clin Oncol 10: 369-374.

[50] Sager O, Dincoglan F, Uysal B, Demiral S, Gamsiz H, et al. (2018) Evaluation of adaptive radiotherapy (ART) by use of replanning the tumor bed boos twith repeated computed tomography (CT) simulation after whole breast irradiation (WBI) for breast cancer patients having clinically evident seroma. Jpn J Radiol 36: 401-406.

[51] Demiral S, Dincoglan F, Sager O, Uysal B, Gamsiz H, et al. (2018) Contemporary Management of Meningiomas with Radio surgery. Int J Radiol Imaging Technol 80: 187-190.

[52] Demiral S, Sager O, Dincoglan F, Uysal B, Gamsiz H, et al. (2018) Evaluation of Target Volume Determination for Single Session Stereotactic Radio surgery (SRS) of Brain Metastases. Canc Therapy \& Oncol Int J 12: 555848 .

[53] Sager O, Dincoglan F, Uysal B, Demiral S, Gamsiz H, et al. (2017) Splenic Irradiation: A Concise Review of the Literature. J App Hem BlTran 1: 101.

[54] Dincoglan F, Sager O, Demiral S, Uysal B, Gamsiz H, et al. (2017) Radio surgery for recurrent glioblastoma: A review article. Neurol Disord Therap 1: 1-5.

[55] Demiral S, Dincoglan F, Sager O, Gamsiz H, Uysal B, et al. (2016) Hypofractionated stereotactic radiotherapy (HFSRT) for who grade I anterior clinoid meningiomas (ACM). Jpn J Radiol 34: 730-737.

[56] Dincoglan F, Beyzadeoglu M, Sager O, Demiral S, Gamsiz H, et al. (2015) Management of patients with recurrent glioblastoma using hypofractionated stereotactic radiotherapy. Tumori 101: 179-184.

[57] Sager O, Dincoglan F, Beyzadeoglu M (2015) Stereotactic radiosurgery of glomus jugulare tumors: Current concepts, recent advances and future perspectives. CNS Oncol 4: 105-114.

[58] Gamsiz H, Beyzadeoglu M, Sager O, Demiral S, Dincoglan F, et al. (2015) Evaluation of stereotactic body radiation therapy in the management of adrenal metastases from nonsmall celllung cancer. Tumori 101: 98-103.
[59] Sager O, Beyzadeoglu M, Dincoglan F, Demiral S, Uysal B, et al. (2015) Adaptive splenic radiotherapy for symptomatic splenomegaly management in myeloproliferative disorders. Tumori 101: 84-90.

[60] Sager O, Beyzadeoglu M, Dincoglan F, Gamsiz H, Demiral S, et al. (2014) Evaluation of linear accelerator-based stereotactic radiosurgery in the management of glomus jugularetumors. Tumori 100: 184-188.

[61] Dincoglan F, Sager O, Gamsiz H, Uysal B, Demiral S, et al. (2014) Management of patients with $\geq 4$ brain metastases using stereotactic radiosurgery boost after whole brain irradiation. Tumori 100: 302-306.

[62] Sager O, Beyzadeoglu M, Dincoglan F, Uysal B, Gamsiz H, et al. (2014) Evaluation of linear ccelerator (LINAC)-based stereotactic radiosurgery (SRS) for cerebral cavernous malformations: A 15-year single-center experience. Ann Saudi Med 34: 54-58.

[63] Gamsiz H, Beyzadeoglu M, Sager O, Dincoglan F, Demiral S, et al. (2014) Management of pulmonary oligometastases by stereotactic body radiotherapy. Tumori 100: 179-183.

[64] Demiral S, Beyzadeoglu M, Sager O, Dincoglan F, Gamsiz H, et al. (2014) Evaluation of linear accelerator (linac)- based stereotactic radiosurgery (srs) for the treatment of craniopharyngiomas. UHOD - Uluslararasi Hematoloji-Onkoloji Dergisi 24: 123-129.

[65] Özsavaş EE, Telatar Z, Dirican B, Sağer Ö, Beyzadeoğlu M (2014) Automatic segmentation of anatomica 1structures from CT scans of thorax for RTP. Comput Math Methods Med 2014: 472890.

[66] Demiral S, Beyzadeoglu M, Sager O, Dincoglan F, Gamsiz H, et al. (2014) Evaluation of Linear Accelerator (Linac)-Based Stereotactic Radiosurgery (Srs) for the Treatment of Craniopharyngiomas. UHODUluslararasi Hematoloji Onkoloji Dergisi 24(2): 123-129.

[67] Demiral S, Beyzadeoglu M, Uysal B, Oysul K, Kahya YE, et al. (2013) Evaluation of stereotactic body radiotherapy (SBRT) boost in the management of end ometrial cancer. Neoplasma 60: 322-327.

[68] Dincoglan F, Beyzadeoglu M, Sager O, Uysal B, Demiral S, et al. (2013) Evaluation of linear accelerator-based stereotactic radiosurgery in the management of meningiomas: A single center experience. J BUON 18: 717-722.

[69] Dincoglan F, Beyzadeoglu M, Sager O, Oysul K, Kahya YE, et al. (2013) Dosimetric evaluation of critical organs at risk in 
mastectomized left-sided breast cancer radiotherapy using breath-hold technique. Tumori 99: 76-82.

[70] Sager O, Beyzadeoglu M, Dincoglan F, Demiral S, Uysal B, et al. (2013) Management of vestibular schwannomas with linear accelerator-based stereotactic radiosurgery: a single center experience. Tumori 99: 617-622.

[71] Dincoglan F, Beyzadeoglu M, Sager O, Oysul K, Sirin S et al. (2012) Image-guided positioning in intracranial non-invasive stereotactic radiosurgery for the treatment of brain metastasis. Tumori 98: 630-635.

[72] Sağer Ö, Dinçoğlan F, Gamsiz H, Demiral S, Uysal B, et al. (2012) Evaluation of the impact of integrated [18f]- fluoro-2-deoxy-D-glucose positron emission tomography/computed tomography imaging on staging and radiotherapy treatment volume definition of non small celllung cancer. Gulhane Med J 54: 220-227.
[73] Sager O, Beyzadeoglu M, Dincoglan F, Oysul K, Kahya YE, et al. (2012) Evaluation of active breathing control-moderate deep inspiration breath-hold in definitive non-small cell lung cancer radiotherapy .Neoplasma 59: 333-340.

[74] Sager O, Beyzadeoglu M, Dincoglan F, Oysul K, Kahya YE, et al. (2012) The Role of Active Breathing Control-Moderate Deep Inspiration Breath-Hold (ABC-mDIBH) Usage in nonMastectomized Left-sided Breast Cancer Radiotherapy: A Dosimetric EvaluationUHOD - Uluslararasi Hematoloji-Onkoloji Dergisi 22: 147-155.

[75] Dincoglan F, Sager O, Gamsiz H, Uysal B, Demiral S, et al. (2012) Stereotactic radiosurgery for intracranial tumors: A single center experience. Gulhane Med J 54: 190-198.

[76] Sirin S, Oysul K, Surenkok S, Sager O, Dincoglan F, et al. (2011) Linear acceleratorbased stereotactic radiosurgery in recurrent glioblastoma: A single center experience. Vojnosanit Pregl 68: 961-966.

Citation: Omer Sager et al., “Omission of Radiation Therapy (RT) for Metaplastic Breast Cancer $(M B C)$ : A Review Article”, International Journal of Research Studies in Medical and Health Sciences. 2021; 6(1): 10-15. DOI: https://doi.org/10.22259/ijrsmhs.0601002

Copyright: (C) 2021 Omer Sager et al., This is an open-access article distributed under the terms of the Creative Commons Attribution License, which permits unrestricted use, distribution, and reproduction in any medium, provided the original author and source are credited. 